\title{
AMENDMENTS
}

\section{Publisher Correction: Phage therapy's latest makeover}

Charles Schmidt

Correction to: Nature Biotechnology https://doi.org/10.1038/s41587-019-0133-z, published online 8 May 2019.

In the version of this article initially published, we listed 13 companies that were developing phage therapies a decade ago and stated that only a few are still active today. Missing from the active list was Phico Therapeutics of Bourn, UK. In addition, a location (Canada) has been added for PhageTech, and "Last May" has been changed to "In May" at the beginning of the article. The errors have been corrected in the HTML and PDF versions of the article.

\section{Author Correction: Comprehensive identification of RNA-protein interactions in any organism using orthogonal organic phase separation (OOPS)}

Rayner M. L. Queiroz, Tom Smith (D), Eneko Villanueva (D), Maria Marti-Solano (D), Mie Monti (D), Mariavittoria Pizzinga, Dan-Mircea Mirea, Manasa Ramakrishna (D), Robert F. Harvey $\mathbb{D}$, Veronica Dezi, Gavin H. Thomas, Anne E. Willis and Kathryn S. Lilley (D)

Correction to: Nature Biotechnology https://doi.org/10.1038/s41587-018-0001-2, published online 3 January 2019.

In the version of this article initially published, Supplementary Table 2, "OOPS cell lines" tab, and Supplementary Table 5, "RNA binding changes (thy-noc)," "Protein abundance (noc)" and "RNA binding changes (noc)" tabs, contained incomplete data with respect to the analysis described in the article. The error has been corrected online. 